\title{
Increasing Safety and Productivity on Egyptian Building Sites
}

\author{
Emad El sayed Etman, Haythem M. Sanad, Noha M. Shoib \\ Structural Engineering, Faculty of Engineering/ Tanta University, Tanta, Egypt \\ Email: Emad.etman@f-eng.tanta.edu.eg, Haytham.Sanad@f-eng.tanta.eduu.eg, noha2166@yahoo.com
}

\begin{abstract}
Safety and productivity in construction industry of Egypt still suffers from ignorance. This low consideration of safety importance caused escalation of accident rate in construction projects. The paper aims to identify the safety factors most related to productivity, and determine their relative importance as perceived by the target audience. The questionnaire was implemented directly; included 4 specific answers (agree, strongly agree, disagree, and strongly disagree) and consists of 47 questions divided into 7 groups: inspection, monitoring, training, etc. These questions were selected from the previous questionnaires and the questions inspired by the topic of this research. The questionnaire was distributed to 67 target audiences of different categories, including Consultants, Site engineers, Site managers and Workers.

The duration of their experience ranges from 0 to more than 15 years, as well as their scientific degrees from Ph.D., Masters, and Bachelor. The following factors are the most important factors of safety and productivity. "Working 7 days per week will increase productivity", " increase productivity ", "Rework will decrease safety", " Incentives based on productivity decreases safety", "Compressed schedules affect negatively safety". The results indicated that "worker problems" are the most important among the groups of productive factors followed by "personal protective equipment", "supervisors and subcontractors", "monitoring", "communication skills". The target audience is advised to work strategically to protect workers by continuing to identify, assess and mitigate hazardous conditions and activities in work sites to achieve the highest levels of safety and productivity.
\end{abstract}

Index terms: Safety; Productivity; personal protective equipment; monitoring; supervisors and subcontractors

\section{INTRODUCTION}

Achieving safety and productivity is a major concern in the construction industry. There is a dearth of effort in the need for simultaneous achievement of safety and productivity on construction sites. (Abdul Rehim, et al. 2008) noted that the causes of accidents were due to poor safety awareness on the part of top leaders; lack of training; poor safety awareness on the part of managers; reluctance to provide security resources; reckless operation; lack of certified skills; lack of equipment; lack of first aid measures; lack of rigorous enforcement of safety regulations; lack of organizational commitment; low educational standards. Accidents cause economic losses and human suffering. Computing the true costs of injuries reveals that compromising safety leads to increased costs and lower profits

Also, (Toole, 2002) listed the major causes of accidents at construction. These are lack of proper training, lack of safety enforcement, lack of safety equipment, unsafe methods or sequencing, unsafe site conditions, failure to use provided safety equipment, poor safety attitude and isolated, sudden deviation from prescribed behavior. Also, highlighted the top causes of construction accidents These include a lack of sufficient training, a lack of safety enforcement, a lack of safety equipment, unsafe procedures or sequencing, unsafe site conditions, a failure to employ available safety equipment, a poor safety attitude, and isolated, unexpected deviations from prescribed conduct.

Site incidents are more likely to occur where there are insufficient organization procedures, inappropriate practices, and dangerous behaviors of building workers, weak dedication management, and sufficient knowledge of safety, and worker training (Teo, et al. 2005).

Productivity is one of the most important factors influencing the success of any construction project. There are three forms of productivity: productivity with a single component, productivity with many factors, and productivity with a total factor (Santosh \& Apte 2014). .According to (Adnan, et al. 2007) one of the most essential aspects influencing the overall success of any small, medium, or big construction sector is productivity. The emerging world recognizes the importance of economic progress and social welfare. The developing countries are experiencing unemployment and recession.

Also, (Aynur, et al. 2008) investigated the effect of basic motivational factors on the productivity of the construction workforce in turkey. Today, human resource also plays a strategic role in any organization's productivity increase, making it superior in industrial competition.

Safety at work is a complex phenomenon and even more so is the subject of safety attitudes and safety performance in the construction sector. Construction is simultaneously acknowledged as a huge economic force and one of the most dangerous (Adnan, et al. 2015)The strategies, in the descending order from the top to the lowest, are; training workers to carry out works properly, especially in the new types of work (under training group), supervisor should be firm with the contractor in safety conditions (under inspection group), foreman should put daily and weekly work plans and define tools that should be used (under monitoring group), drug test for workers (under monitoring group), and scheduling adequate number of workers 
to complete the heavy tasks, which helps to decrease injuries, as well as to foster a spirit of teamwork and increase productivity

The Health and Safety Policy Statement of (Phi Hughes et al. 2001) will contain objectives that are not tangible and objectives that are observable by the company or organization. During policy changes, targets are likely to remain constant, while objectives are checked and altered or modified each year. Insurance providers play a significant part in the development of health and safety practices. This requirement is exempted by certain public sector organizations because any compensation is paid out of public funds. There has been a substantial rise in the number and scale of reimbursement settlements in recent years and this has placed more pressure on insurance providers.

\section{RESULTS AND DISCUSSION}

This section describes the study of a survey questionnaire obtained from 67 respondents. The obtained data were examined using a basic statistical analytical method such as percentages, charts, tables and an overview of the results. This questionnaire consists of 47 questions divided into 7 main groups, and each group of questions is divided into 3 sub-types: productivity and safety and both.

\section{Group 1: Inspection}

Table 1 shows the respondents' perceptions about the effect of inspections on safety and productivity and Relative importance index and also shows the relative importance index for Inspection. Determined the maximum mean for sub- criteria is Supervisor should be firm with the contractor in safety conditions because it will positively affect productivity (1.8806) and the minimum mean for sub- criteria is Coordination between the contractor and the ministry of labor increase safety standards (1.5224). This group contains five factors of inspection:

"Supervisor should be firm with the contractor in safety conditions because it will positively affect productivity" factor was ranked in the first position among inspection group with $\mathrm{RII}=0.4702$ and was ranked in the 20 position among all groups factors of safety and productivity.

"Involvement of foreman in preparing schedule, increase productivity and safety" factor was ranked in the second position among inspection group with $\mathrm{RII}=0.4590$ and was ranked in the 23 position among all groups factors of safety and productivity. This result indicates the importance of the foreman in maintaining a safer and more productive job site. Because foremen have direct contact with workers and job sites, they are well- versed in safety procedures. They can advise the project manager on the ideal time to complete a work in order to complete it safety.

\section{Group 2: Monitoring}

Table 2 shows the respondents' perceptions about the effect of monitoring on safety and productivity and also determined the maximum mean for sub-criteria is Working 7 days per week will increase productivity (3.0448) and the minimum mean for sub-criteria is Foreman and supervisor should have communication skills with workers to manage safety and to obtain higher productivity(1.5672). This group contains eight factors of monitoring "Working 7 days per week will increase productivity" "factor was ranked in the first position among inspection group with $\mathrm{RII}=0.7612$ and was ranked in the 1 position among all groups factors of safety and Figure: Relative Importance Histogram for monitoring productivity. This result indicates that working 7 days per week without holiday does not affect productivity.

"Working 7 days per week will decrease safety hazard" factor was ranked in the second position among inspection group with $\mathrm{RII}=0.5261$ and was ranked in the 11 position among all groups factors of safety and productivity. This result indicates that working 7 days per week without holiday does not affect safety.

\section{Group 3: Training and coordination}

Table shows the respondents' perceptions about the effect of Training and coordination on safety and productivity and also determined the maximum mean for sub-criteria is The main case of the accidents on the site is the workers (2.3433) and the minimum mean for sub-criteria is Workers should be trained about dealing with changes in working conditions to get excellent productivity (1.4328) .This group contains eleven factors of training and coordination.

"The main case of the accidents on the site is the workers lack for safety knowledge" factor was ranked in the $1^{\text {st }}$ position among Training and coordination group with $\mathrm{RII}=0.5858$ and was ranked in the 8 position among all groups factors of safety and productivity.

"Night- shift will decrease productivity" factor was ranked in the $2^{\text {nd }}$ position among Training and coordination group with $\mathrm{RII}=0.5336$ and was ranked in the 10 position among all groups factors of safety and productivity.

Table 1: Effect of inspection and the relative importance index

\begin{tabular}{|c|c|c|c|c|c|c|c|c|c|}
\hline \multirow[b]{2}{*}{ Inspection } & \multicolumn{4}{|c|}{ Frequency of occurrence } & \multirow[b]{2}{*}{ RII } & \multirow{2}{*}{$\begin{array}{c}\text { Rank within } \\
\text { group }\end{array}$} & \multirow[b]{2}{*}{ Rank } & \multirow[b]{2}{*}{ Mean } & \multirow[b]{2}{*}{ Percentage } \\
\hline & $\begin{array}{l}\text { Strongly } \\
\text { agree }\end{array}$ & Agree & Disagree & $\begin{array}{l}\text { Strongly } \\
\text { Disagree }\end{array}$ & & & & & \\
\hline $\begin{array}{l}\text { Allocating tasks to workers } \\
\text { increase productivity }\end{array}$ & 33 & 32 & 2 & 0 & .3843 & 4 & 43 & 1.5373 & $38.43 \%$ \\
\hline $\begin{array}{l}\text { Over-inspection by foreman } \\
\text { increase productivity }\end{array}$ & 23 & 36 & 6 & 2 & .4515 & 3 & 26 & 1.8060 & $45.15 \%$ \\
\hline $\begin{array}{c}\text { Coordination between the contractor and } \\
\text { the ministry of labor increase safety } \\
\text { standards }\end{array}$ & 38 & 24 & 4 & 1 & .3806 & 5 & 45 & 1.5224 & $38.06 \%$ \\
\hline \begin{tabular}{|c|}
$\begin{array}{c}\text { Supervisor should be firm with the } \\
\text { contractor in safety conditions because it } \\
\text { will positively affect productivity }\end{array}$ \\
\end{tabular} & 33 & 15 & 13 & 6 & .4702 & 1 & 20 & 1.8806 & $47.02 \%$ \\
\hline $\begin{array}{c}\text { Involvement of foreman in preparing } \\
\text { schedule, increase productivity and } \\
\text { safety }\end{array}$ & 26 & 29 & 9 & 3 & .4590 & 2 & 23 & 1.8358 & $45.89 \%$ \\
\hline
\end{tabular}


Table 2: Effect of Monitoring and Relative Importance Index

\begin{tabular}{|c|c|c|c|c|c|c|c|c|c|}
\hline \multirow[b]{2}{*}{ Monitoring } & \multicolumn{4}{|c|}{ Frequency of occurrence } & \multirow[b]{2}{*}{ RII } & \multirow{2}{*}{$\begin{array}{l}\text { Rank within } \\
\text { group }\end{array}$} & \multirow[b]{2}{*}{ Rank } & \multirow[b]{2}{*}{ Mean } & \multirow[b]{2}{*}{ Percentage } \\
\hline & $\begin{array}{c}\begin{array}{c}\text { Strongly } \\
\text { agree }\end{array} \\
\end{array}$ & Agree & Disagree & $\begin{array}{l}\text { Strongly } \\
\text { Disagree }\end{array}$ & & & & & \\
\hline $\begin{array}{l}\text { Giving workers breaks time, and urges } \\
\text { workers to take a rest when feeling tired } \\
\text { will increase productivity }\end{array}$ & 25 & 33 & 8 & 1 & .4444 & 5 & 29 & 1.7761 & $44.403 \%$ \\
\hline $\begin{array}{c}\text { Working } 7 \text { days per week will increase } \\
\text { productivity }\end{array}$ & 5 & 9 & 31 & 22 & .7612. & 1 & 1 & 3.0448 & $76.12 \%$ \\
\hline $\begin{array}{c}\text { Safety program contributes to increase } \\
\text { productivity }\end{array}$ & 16 & 41 & 9 & 1 & .4814. & 3 & 19 & 1.9254 & $48.14 \%$ \\
\hline $\begin{array}{c}\text { Working } 7 \text { days per week will decrease } \\
\text { safety hazard }\end{array}$ & 23 & 25 & 8 & 11 & .5261. & 2 & 11 & 2.1045 & $52.61 \%$ \\
\hline $\begin{array}{l}\text { Giving workers breaks time, and urges } \\
\text { workers to take a rest when feel tired and } \\
\text { fatigue will increase safety }\end{array}$ & 29 & 28 & 7 & 3 & .4403 & 6 & 31 & 1.7612 & $44.03 \%$ \\
\hline $\begin{array}{c}\text { Monitoring the schedule of safety meeting } \\
\text { contributes to increase productivity }\end{array}$ & 26 & 34 & 4 & 3 & .4403 & 7 & 32 & 1.7612 & $44.03 \%$ \\
\hline $\begin{array}{l}\text { Foreman and supervisor should have } \\
\text { communication skills with workers to } \\
\text { manage safety and to obtain higher } \\
\text { productivity }\end{array}$ & 41 & 17 & 6 & 3 & .3918 & 8 & 42 & 1.5672 & $39.18 \%$ \\
\hline $\begin{array}{c}\text { If supervisors promote safe work } \\
\text { habits, this will increase in productivity and } \\
\text { safety }\end{array}$ & 27 & 26 & 9 & 5 & .4702 & 4 & 21 & 1.8806 & $47.02 \%$ \\
\hline
\end{tabular}

Table 3: Effect of Training and coordination and Relative Importance Index

\begin{tabular}{|c|c|c|c|c|c|c|c|c|c|}
\hline \multirow{2}{*}{ Training and coordination } & \multicolumn{4}{|c|}{ Frequency of occurrence } & \multirow{2}{*}{ RII } & \multirow{2}{*}{$\begin{array}{l}\text { Rank within } \\
\text { group }\end{array}$} & \multirow{2}{*}{ Rank } & \multirow{2}{*}{ Mean } & \multirow{2}{*}{ Percentage } \\
\hline & $\begin{array}{c}\text { Strongly } \\
\text { agree }\end{array}$ & Agree & Disagree & $\begin{array}{l}\text { Strongly } \\
\text { Disagree }\end{array}$ & & & & & \\
\hline $\begin{array}{l}\text { Training workers to carry out works } \\
\text { properly, especially in the new types of } \\
\text { work, will increase productivity }\end{array}$ & 38 & 22 & 7 & 0 & ,3843 & 10 & 44 & 1.5373 & $38.43 \%$ \\
\hline $\begin{array}{l}\text { Workers should be trained about dealing } \\
\text { with changes in working conditions to get } \\
\text { excellent productivity }\end{array}$ & 41 & 23 & 3 & 0 & .3582 & 11 & 46 & 1.4328 & $35.82 \%$ \\
\hline $\begin{array}{c}\text { When workers have experience } \\
\text { and education, productivity will increase }\end{array}$ & 34 & 27 & 4 & 2 & .4030 & 9 & 41 & 1.6119 & $40.30 \%$ \\
\hline Hot weather decrease productivity & 28 & 31 & 8 & 0 & .4254 & 5 & 36 & 1.7015 & $42.54 \%$ \\
\hline Housekeeping increase productivity & 36 & 22 & 7 & 2 & .4067 & 8 & 40 & 1.6269 & $40.67 \%$ \\
\hline Night- shift will decrease productivity & 19 & 25 & 18 & 5 & .5336 & 2 & 10 & 2.1343 & $53.36 \%$ \\
\hline
\end{tabular}

\section{Group 4: personal protective equipment}

Table 4 shows the respondents' perception about the effect of personal protective equipment on safety and productivity also shows the relative importance index for Personal protective equipment. Determined the maximum mean for sub-criteria is Use of PPE puts constraints on workers movement which decrease productivity(2.6716) and the minimum mean for sub-criteria is Improvement of equipment and tools , Improve safety and productivity(1.7164)

This group contains eleven factors of training and coordination. "Productivity is affected negatively when workers don't wear PPE" factor was ranked in the $3^{\text {rd }}$ position among personal protective equipment group with $\mathrm{RII}=0.4963$ and was ranked in the 14 position among all groups factors of safety and productivity.

"Use of PPE puts constraints on workers movement which decrease productivity" factor was ranked in the $1^{\text {st }}$ position among personal protective equipment group with $\mathrm{RII}=0.6679$ and was ranked in the 3 position among all groups factors of safety and productivity.

"Safety is affected negatively, when workers don't wear PPE" factor was ranked in the $2^{\text {nd }}$ position among personal protective equipment group with $\mathrm{RII}=0.5000$ and was ranked in the 12 position among all groups factors of safety and productivity.

"Improvement of equipment and tools, Improve safety and productivity" factor was ranked in the $4^{\text {th }}$ position among personal protective equipment group with $\mathrm{RII}=0.4291$ and was ranked in the 35 position among all groups factors of safety and productivity.

\section{Group 5: Communication skills}

Table 5 shows the respondents' perceptions about the effect of Communication skills on safety and productivity and also shows the relative importance index.

Determined the maximum mean for sub-criteria is Incentives based on productivity decreases safety (2.4328) and the minimum mean for sub-criteria is Use of modern labor equipment, contributes to increase of safety of workers (1.6716) This group contains seven factors of training and coordination. "Incentives based on productivity decreases safety" factor was ranked in the $1^{\text {st }}$ position among Communication skills group with $\mathrm{RII}=0.6082$ and was ranked in the 4 position among all groups factors of safety and productivity. 
Table 4: Effect of personal protective equipment and Relative Importance Index

\begin{tabular}{|c|c|c|c|c|c|c|c|c|c|}
\hline \multirow[b]{2}{*}{ Personal protective equipment } & \multicolumn{4}{|c|}{ Frequency of occurrence } & \multirow[b]{2}{*}{ RII } & \multirow{2}{*}{$\begin{array}{c}\text { Rank within } \\
\text { group }\end{array}$} & \multirow[b]{2}{*}{ Rank } & \multirow[b]{2}{*}{ Mean } & \multirow[b]{2}{*}{ Percentage } \\
\hline & $\begin{array}{l}\text { Strongly } \\
\text { agree }\end{array}$ & Agree & Disagree & $\begin{array}{l}\text { Strongly } \\
\text { Disagree }\end{array}$ & & & & & \\
\hline $\begin{array}{l}\text { productivity is affected negatively when } \\
\text { workers don't wear PPE }\end{array}$ & 21 & 29 & 14 & 3 & .4963 & 3 & 14 & 1.9851 & $49.63 \%$ \\
\hline $\begin{array}{l}\text { Use of PPE puts constraints on workers } \\
\text { movement which decrease productivity }\end{array}$ & 6 & 20 & 31 & 10 & .6679 & 1 & 3 & 2.6716 & $66.79 \%$ \\
\hline \begin{tabular}{|c|} 
Safety is affected negatively, when workers \\
don't wear PPE
\end{tabular} & 17 & 36 & 11 & 3 & .5000 & 2 & 12 & 2.0000 & $50 \%$ \\
\hline $\begin{array}{l}\text { Improvement of equipment and tools, } \\
\text { Improve safety and productivity }\end{array}$ & 30 & 26 & 11 & 0 & .4291 & 4 & 35 & 1.7164 & $42.91 \%$ \\
\hline
\end{tabular}

Table 5: Effect of Communication skills and Relative Importance Index

\begin{tabular}{|c|c|c|c|c|c|c|c|c|c|}
\hline \multirow[b]{2}{*}{ Communication skills } & \multicolumn{4}{|c|}{ Frequency of occurrence } & \multirow[b]{2}{*}{ RII } & \multirow{2}{*}{$\begin{array}{c}\text { Rank within } \\
\text { group }\end{array}$} & \multirow[b]{2}{*}{ Rank } & \multirow[b]{2}{*}{ Mean } & \multirow[b]{2}{*}{ Percentage } \\
\hline & $\begin{array}{l}\text { Strongly } \\
\text { agree }\end{array}$ & Agree & Disagree & $\begin{array}{l}\text { Strongly } \\
\text { Disagree }\end{array}$ & & & & & \\
\hline $\begin{array}{c}\text { Periodically safety meetings for mangers, } \\
\text { engineers and workers, affect positively on } \\
\text { productivity }\end{array}$ & 27 & 29 & 8 & 3 & .4515 & 4 & 27 & 1.8060 & $45.15 \%$ \\
\hline $\begin{array}{c}\text { Training old and new workers on } \\
\text { preventive actions and first aid increases } \\
\text { productivity }\end{array}$ & 27 & 29 & 9 & 2 & .4478 & 5 & 28 & .7910 & $44.78 \%$ \\
\hline $\begin{array}{c}\text { Incentives based on productivity decreases } \\
\text { safety }\end{array}$ & 10 & 29 & 17 & 11 & .6082 & 1 & 4 & 2.4328 & $60.82 \%$ \\
\hline $\begin{array}{c}\text { Cooperation between work groups always } \\
\text { enhance safety climate }\end{array}$ & 21 & 33 & 8 & 5 & .4888 & 2 & 15 & 1.9552 & $48.88 \%$ \\
\hline $\begin{array}{c}\text { Use of modern labor equipment, } \\
\text { contributes to increase of safety of workers }\end{array}$ & 36 & 21 & 6 & 4 & .4179 & 7 & 38 & 1.6716 & $41.79 \%$ \\
\hline $\begin{array}{c}\begin{array}{c}\text { Experience of worker improves safety and } \\
\text { increases productivity }\end{array} \\
\end{array}$ & 28 & 28 & 11 & 0 & .4366 & 6 & 33 & 1.7463 & $43.66 \%$ \\
\hline Safety signs improves productivity & 18 & 41 & 8 & 0 & .4627 & 3 & 22 & 1.8507 & $46.27 \%$ \\
\hline
\end{tabular}

"Cooperation between work groups always enhance safety climate" factor was ranked in the $2^{\text {nd }}$ position among Communication skills group with $\mathrm{RII}=0.4888$ and was ranked in the 15 position among all groups factors of safety and productivity.

\section{Group 6: Worker problems}

Table 6 shows the respondents' perceptions about the effect of Worker problems on safety and productivity and shows the relative importance index for Worker problems. Determined the maximum mean for sub-criteria is Rework will decrease safety (2.7910) and the minimum mean for sub-criteria is Safety and productivity is affected negatively when workers perform work without supervision of a foreman (1.8308). This group contains seven factors of training and coordination

"Rework will decrease safety" factor was ranked in the $1^{\text {st }}$ position among Worker problems group with $\mathrm{RII}=0.6978$ and was ranked in the 2 position among all groups factors of safety and productivity.

Non fair workload distribution on workers affect productivity badly" factor was ranked in the $2^{\text {nd }}$ position among Worker problems group with $\mathrm{RII}=0.5858$ and was ranked in the 7 position among all groups factors of safety and productivity.

\section{Group 7: Supervisors and subcontractors}

Table 7 shows the respondents' perceptions about the effect of Supervisors and subcontractors on safety and productivity and also shows the relative importance index for Supervisors and subcontractors. Determined the maximum mean for sub-criteria is Compressed schedules affect negatively safety Compressed schedules affect negatively safety (2.4328) and the minimum mean for sub-criteria is Improvement in safety knowledge of supervisors improves safety (1.7164) This group contains seven factors of training and coordination
"Compressed schedules affect negatively safety" factor was ranked in the $1^{\text {st }}$ position among Supervisors and subcontractors group with $\mathrm{RII}=0.6082$ and was ranked in the 5 position among all groups factors of safety and productivity.

"Compressed schedules affect negatively productivity" factor was ranked in the $2^{\text {nd }}$ position among Supervisors and subcontractors group with $\mathrm{RII}=0.5933$ and was ranked in the 6 position among all groups factors of safety and productivity.

\section{The Analytic network Process (ANP)}

ANP is the most powerful synthesis methodologies for combining judgment and data to effectively rank options and predict outcomes. A network can be grouped into source clusters, intermediate clusters, and sink clusters. Arcs reflect relationships in a network, and the directions of the arcs indicate directional dependence (Chang et al., 2006 and Sarkis, 2002). The analytic network process (ANP) is more general from of the analytic hierarchy process (AHP) used in multi- criteria decision analysis.

The Analytic Network Process (ANP)'s lies in its use of ratio scales to capture all types of interactions and make accurate predictions, and even better decisions. So far, it has proven to be a success when expert expertise has been combined with it to forecast sports results, economic turns, industry, social, and political events. The 3 contractors refer to 3 levels of solutions which are high, medium and low as expected to achieve both safety and productivity.

\section{ANP Model}

ANP represents a decision-making problem as a network of criteria and options (collectively referred to as elements) that are organized into clusters. All of the parts in the network can be linked in any way feasible, i.e. a network can have feedback and interdependence interactions inside and between clusters. This allows for more realistic modeling of complex situations. 
Table 6: Effect of Worker problems and Relative Importance Index

\begin{tabular}{|c|c|c|c|c|c|c|c|c|c|}
\hline \multirow[b]{2}{*}{ Worker problems } & \multicolumn{4}{|c|}{ Frequency of occurrence } & \multirow[b]{2}{*}{ RII } & \multirow[b]{2}{*}{$\begin{array}{c}\text { Rank within } \\
\text { group }\end{array}$} & \multirow[b]{2}{*}{ Rank } & \multirow[b]{2}{*}{ Mean } & \multirow[b]{2}{*}{ Percentage } \\
\hline & $\begin{array}{c}\text { Strongly } \\
\text { agree }\end{array}$ & Agree & Disagree & $\begin{array}{l}\text { Strongly } \\
\text { Disagree }\end{array}$ & & & & & \\
\hline $\begin{array}{l}\text { Non fair workload distribution on workers } \\
\text { affect productivity badly }\end{array}$ & 10 & 28 & 25 & 4 & .5858 & 2 & 7 & 2.3433 & $58.58 \%$ \\
\hline $\begin{array}{c}\text { Absence of workers without cause will } \\
\text { decrease productivity }\end{array}$ & 21 & 38 & 6 & 2 & .4590 & 4 & 24 & 1.8358 & $45.90 \%$ \\
\hline Rework will decrease safety & 6 & 18 & 27 & 16 & .6978 & 1 & 2 & 2.7910 & $69.78 \%$ \\
\hline $\begin{array}{l}\text { Safety and productivity is affected } \\
\text { negatively when workers perform work } \\
\text { without supervision of a foreman }\end{array}$ & 21 & 36 & 6 & 4 & .4577 & 5 & 25 & 1.8308 & $45.77 \%$ \\
\hline $\begin{array}{l}\text { Personal and family problems of worker } \\
\text { affect negatively on safety and productivity }\end{array}$ & 18 & 34 & 12 & 3 & .5000 & 3 & 13 & 2.0000 & $50 \%$ \\
\hline
\end{tabular}

Table 7: Effect of Supervisors and subcontractors and Relative Importance Index

\begin{tabular}{|c|c|c|c|c|c|c|c|c|c|}
\hline \multirow[b]{2}{*}{ Supervisors and subcontractors } & \multicolumn{4}{|c|}{ Frequency of occurrence } & \multirow[b]{2}{*}{ RII } & \multirow{2}{*}{$\begin{array}{c}\text { Rank within } \\
\text { group }\end{array}$} & \multirow[b]{2}{*}{ Rank } & \multirow[b]{2}{*}{ Mean } & \multirow[b]{2}{*}{ Percentage } \\
\hline & $\begin{array}{l}\text { Strongly } \\
\text { agree }\end{array}$ & Agree & Disagree & $\begin{array}{l}\text { Strongly } \\
\text { Disagree }\end{array}$ & & & & & \\
\hline $\begin{array}{l}\text { If more time and money are } \\
\text { available for supervising this will improve } \\
\text { productivity }\end{array}$ & 22 & 39 & 6 & 0 & .4403 & 5 & 30 & 1.7612 & $44.03 \%$ \\
\hline $\begin{array}{l}\text { Accidents frustrate workers which would } \\
\text { decrease productivity }\end{array}$ & 15 & 42 & 8 & 2 & .4888 & 4 & 16 & 1.9552 & $48.88 \%$ \\
\hline $\begin{array}{c}\text { Compressed schedules affect negatively } \\
\text { productivity }\end{array}$ & 14 & 19 & 29 & 5 & .5933 & 2 & 6 & 2.3731 & $59.33 \%$ \\
\hline $\begin{array}{c}\text { Compressed schedules affect negatively } \\
\text { safety }\end{array}$ & 16 & 26 & 23 & 2 & .6082 & 1 & 5 & 2.4328 & $60.82 \%$ \\
\hline
\end{tabular}

A super matrix can be used to illustrate the influence of network elements on other network elements. Figure 1 shows an overview of the new decision network model. In this model, the main difference from the original is the presence of a feedback loop in the level of selection criteria. It is assumed that the seventh selection criteria are interrelated.

\section{Super decisions Software}

The Analytic Network Process (ANP) for decision making with reliance and feedback, invented by Thomas L. Saaty, is implemented in the Super Decisions software.

The Super Decisions software is a simple and easy-to-use tool for constructing decision models with dependence and feedback and computing results using the Analytic Network Process's super matrices. This software was designed to run in a variety of computing environments other than Windows. There is also a web-based version.

\section{Use of the proposed ANP model}

Figure 1 depicts the network model used to determine the weights of the factors to be used in the Information Manufacturing System Performance Indicator. ANP comprises four main steps:

(1) Conducting pair-wise comparisons on the elements at the cluster and sub-cluster levels;

(2) Placing the resulting relative importance weights (eigenvectors) in sub matrices within the super matrix;

(3) Adjusting the values in the super matrix so that the super matrix can achieve column stochastic; and

(4) Raising the super matrix to limiting powers until the weights have converged and remain stable.

\section{ANP's Advantages and Disadvantages}

One of the advantages of ANP over other MCDM techniques is that it examines interactions inside clusters of elements and within clusters, as well as feedback between them.

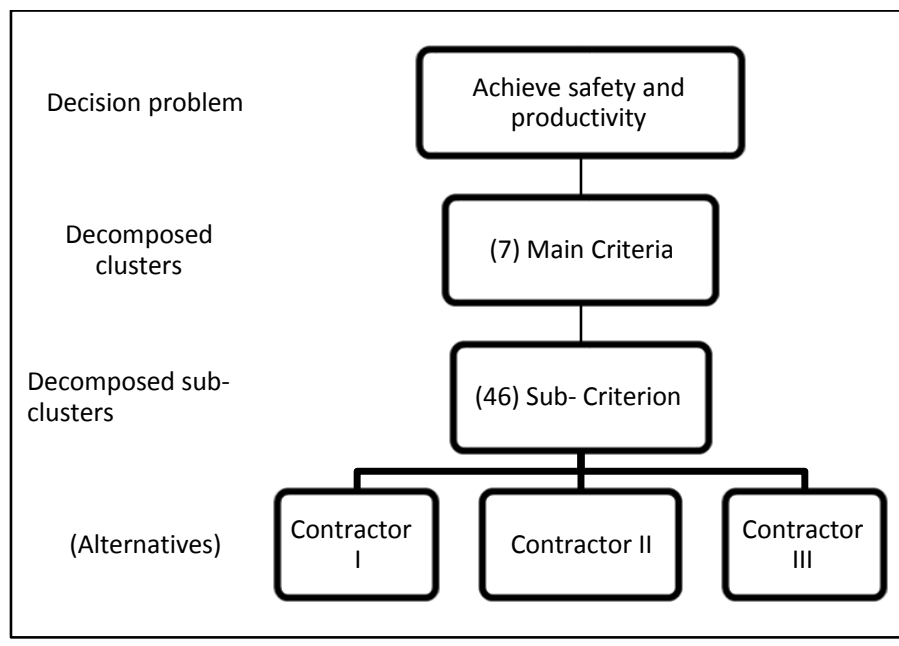

Figure 1. The ANP model

Another advantage of the ANP is that it evaluates decision accuracy. If the decisions are inconsistent, they should be rejudged in order to attain the appropriate level of consistency. Outlines some advantages of AHP/ANP over other MCDM methods:

1. Mathematically demonstrated, eigenvector approach, and accurate methodology.

2. Variable interrelationships between factors

3. Allows for the presence of dependency between criteria.

4. Evaluation consistency.

5. Interdependence and feedback loops between network layers

Outlines some disadvantages of AHP/ANP over other MCDM methods: 
1. It is difficult for the general population to populate the supermatrix.

2. Hierarchy isn't always as rigorous as it should be.

3. Factor interrelationships are rigid.

4. When the decision structure is mostly hierarchical, AHP is more effective mathematically.

\section{Concepts of the Analytic Network Process}

1- Feedback, inner and outer dependency

2 - Influence in relation to a criterion.

3- The command and control hierarchy or system.

4- The supermatrix.

5- The limiting supermatrix and priorities

6- Primitiveness, irreducibility, and cyclicity.

7- Generate a stochastic limiting supermatrix: this is why clusters must be compared.

8- Synthesis of control hierarchy or control system criteria.

9- Control hierarchies for benefits, costs, opportunities, and hazards to compute the limit.

10- Formulation.

11- Relationship to the Neural Network The continuous case is being fired.

12- The density of neuronal firing and distributions, as well as their applicability to visual reproduction graphics as well as orchestral compositions. More research in this area is required.

\section{Fundamental ideas in support of the ANP are:}

1-The ANP is built on the AHP.

2- By allowing for dependence, the ANP goes beyond the AHP by including independence and hence also the AHP as a special case;

3- Deals with dependence within a set of elements (inner dependence), and among different sets of elements (outer dependence);

4- The looser network structure of the ANP makes possible the representation of any decision problem without concern for what comes first and what comes next as in a hierarchy;

5- The ANP is a nonlinear structure that deals with sources, cycles, and sinks. A hierarchy is linear, with a goal in the top level, and the alternatives in the bottom level;

6- Prioritizes not just elements but also groups or a cluster of elements as is often necessary in the real world;

7- Utilizes the idea of a control hierarchy or a control network to deal with different criteria, eventually leading to the analysis of benefits, opportunities, costs, and risks. By relying on control elements, the ANP parallels what the human brain does in combining different sense data as for example does the thalamus.

\section{Conclusion}

The primary objective of this questionnaire was to identify and study the relative importance of safety and productivity factors, according to the perception of the target audience. Forty-seven factors have been identified and arranged, which are also grouped under seven major categories. Table (8) shows the top five factors that are closely related to safety and productivity based on the overall ranking. The element "working 7 days per week will increase productivity" ranked highest in terms of importance in preserving the project's safety and productivity, according to the findings. This factor belongs to Monitoring. Results show that skilled workers enhance safety. This factor shows the significant linkage between safety and productivity.

The results showed that the factor "rework will reduce safety" was ranked second. This factor belongs to the group of workers' problems. This factor of productivity is analogous to the factor of "unfair distribution of workload among workers badly affects productivity". This indicates that the unfair distribution of work negatively affects productivity. Showing the daily activities of workers helps to avoid inconsistencies with safety regulations.

The results showed that "the use of personal protective equipment places restrictions on the movement of workers which reduces productivity" ranked third. This factor indicates the importance of a productivity program in maintaining a safe workplace environment. Indicates that a safety program enhances productivity by reducing accidents and injuries.

Table 8. The most important factors that relate to safety and productivity

\begin{tabular}{|c|c|c|c|}
\hline Factors of productivity and safety & Related group & RII & Rank \\
\hline $\begin{array}{c}\text { Working 7 days per week will } \\
\text { increase productivity. }\end{array}$ & Monitoring & .7612. & 1 \\
\hline Rework will decrease safety & Worker problems & .6978 & 2 \\
\hline $\begin{array}{c}\text { Use of PPE puts constraints on } \\
\text { workers movement which decrease } \\
\text { productivity }\end{array}$ & $\begin{array}{c}\text { Personal protective } \\
\text { equipment }\end{array}$ & .6679 & 3 \\
\hline $\begin{array}{c}\text { Incentives based on productivity } \\
\text { decreases safety }\end{array}$ & Communication Skills & .6082 & 4 \\
\hline $\begin{array}{c}\text { Compressed schedules affect } \\
\text { negatively safety }\end{array}$ & $\begin{array}{c}\text { Supervisors and } \\
\text { Subcontractors }\end{array}$ & .6082 & 5 \\
\hline
\end{tabular}

\section{References}

[1] Abdul Rahim A, H, Muhd, Z, Abd Majid, B, S, (2008), Malaysian journal of Civil Engineering 20(2):242-259(2008)

[2] Toole, T.M (2002), Construction site Safety Roles', Journal of Construction Engineering and Management, (2002), Volume 128(3),pp 203-210

[3] Teo, E. A. L.; Ling, F. Y. Y.; Chong, A. F. W. 2005. Framework for project managers to manage construction safety, International Journal of Project Management 23(4): 329-341.

[4] Santosh.E., Apte.M. 2014. Loss in Productivity in Relation with Delay Analysis in Building Construction Projects. IOSR Journal of Mechanical and Civil Engineering.

[5] Adnan,E.,Sherif, M.,Ziad ,A. M. and Peter,E.,M.2007. Factors Affecting Labour Productivity In Building Projects In The Gaza Strip. Journal of Civil Engineering And Management. Vol XIII, Nov 4, 245 254.

[6] Aynur, K.,Ekrem, M. and Serdar, U. 2008. Effect of basic motivational factors on construction workforce productivity in Turkey. Journal of Civil Engineering and Management 14(14):95-106.

[7] Adnan,E., Lina, A.2015 . Strategies For Safety And Productivity Improvement. Journal Of Engineering Research And Technology, Volume 2, Issue 1

[8] Phi Hughes, Fciosh, Rsp, Chainman NEBOSH (1995-2001), Book, Introduction to Health and Safety in Construction Projects (1995-2001. 